\title{
Better ceramic substrates through zeolites
}

\author{
M A SUBRAMANIAN, D R CORBIN and U CHOWDHRY* \\ E. I. duPont de Nemours and Company, Central Research and Development, Experimental \\ Station, Wilmington, Delaware 19880-0328, USA \\ *Current address: Jackson Laboratory, E. I. du Pont de Nemours and Company, Chambers \\ Works, Deepwater, New Jersey 08023, USA
}

\begin{abstract}
A novel synthetic route for fabricating dense aluminosilicate-based ceramics at relatively low temperatures $\left(\leqslant 1000^{\circ} \mathrm{C}\right)$ is described. The method involves ion exchange of an appropriate zeolite powder, followed by fabrication and sintering, to form a dense ceramic. Anorthite, cordierite- and $\beta$-spodumene-based ceramic substrates with attractive physical properties for microelectronic packaging are obtained using these unusual precursors. A brief overview on the property requirements for substrates used in microelectronic packaging is outlined at the beginning of the article.
\end{abstract}

Keywords Zeolites; precursors; ceramics; microelectronic packaging; anorthite; cordierite.

\section{Introduction to microelectronic packaging}

The continuing desire for faster and denser electronic microcircuits leads to challenges in the design of substrate materials on both the atomic and micron scales. This section will review the materials and processing requirements for ceramic substrates used in microelectronic packaging. The integrated circuitry (IC) on a silicon chip is the central component of all logic and memory functions on which today's computers and other electronic systems are based. The term microelectronic packaging refers to the assembly of functions that support, protect, provide power to, and transmit signals from the IC chip (Harper and Staley 1985; Chowdhry and Sleight 1987). A schematic diagram of a multilayer package is shown in figure 1 depicting several insulating layers of a ceramic-glass thick film paste screen printed and sintered onto a rigid alumina substrate. The chip is bonded to the top insulating layer that also houses various conducting circuit patterns. Interconnections to the patterns in the layers below are provided by 'via holes'.

Important substrates for electronic interconnection may be broadly divided into three major categories: ceramic-based, polymer-printed circuit-board-based, and structures built up on a metal core. For high performance packages in which thermal stability and impermeability are essential, ceramic-based packages are preferred over plastics (Wilcox 1971; Schwartz 1984a; Tummala 1988). The industry trend in ceramic packages is toward cofired multilayer structures that involve casting ceramic tape, metallization, lamination, and simultaneous sintering of the insulating layer and conducting components (Schwartz 1984b). The substrate material most widely used today is alumina $\left(\alpha-\mathrm{Al}_{2} \mathrm{O}_{3}\right)$ which is traditionally sintered at $1600^{\circ} \mathrm{C}$. This high sintering temperature necessitates the use of refractory metals such as Mo and W to form the conducting patterns. The material of choice for future conductors is $\mathrm{Cu}$ because of its high conductivity and low cost. However, the use of $\mathrm{Cu}$ requires a ceramic system that sinters to high density below $1000^{\circ} \mathrm{C}$ in a non-oxidizing atmosphere. 


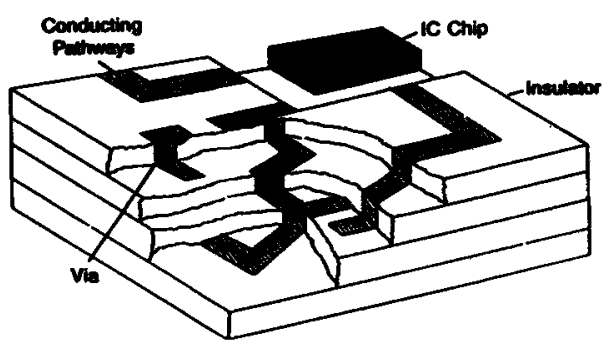

Figure 1. Schematic diagram of a multilayer ceramic microelectronic package.

Table 1. Property requirements of substrates for electronic packaging.

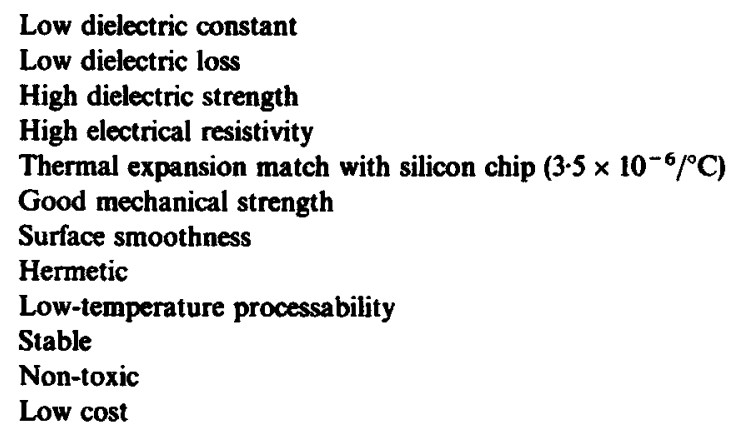

\subsection{Substrate properties}

The property requirements of substrate materials for microelectronic packaging are listed in table 1 .

1.1a Dielectric properties: The two parameters of transmission line conductors of most importance in designing high speed circuitry are velocity of propagation and characteristic impedance (Harper and Staley 1985). Both are related to the dielectric constant of the substrate. The time delay for signal propagation is given by

$$
t_{\mathrm{d}}=\sqrt{\frac{\kappa l}{c}},
$$

where $\kappa$ is the dielectric constant of the substrate, $l$ the distance the signal must travel, and $c$ the velocity of light.

Hence, the dielectric constant of the substrate should be as low as possible. The highest velocity of propagation is obtained for a conductor surrounded by air or vacuum with a dielectric constant of $1 \cdot 0$. With high speed devices, it is important to match the transmission line impedance to the specific device input impedance. In addition to dielectric constant, conductor line width and dielectric thickness must be controlled for impedance matching (Harper and Staley 1985).

The lowest dielectric constants will generally occur for highly covalently bonded materials with low atomic number. Thus, certain organic materials would be preferred as substrates if dielectric properties were the only consideration. Glasses can have 
desirable dielectric properties, but they have inferior mechanical strength and thermal conductivity.

Dielectric losses $(\tan \delta)$ in materials occur at various frequencies and are related to various polarization mechanisms (von Hippel 1954). Generally, these loss peaks must be avoided. Dielectric losses greater than 0.005 are usually considered unacceptable for substrate applications since dielectric loss results in conversion of electrical energy into heat.

The electrical resistivities of the substrate should be very high, greater than $10^{12} \mathrm{ohm}-\mathrm{cm}$ at ambient temperatures, so that there is little chance of current leakage between conductor lines. Presence of mobile cation impurities such as $\mathrm{Na}, \mathrm{K}, \mathrm{Li}, \mathrm{Cu}$ or Ag at significant levels should be avoided since they can degrade the insulation resistance (Schwartz 1984a).

1.1b Thermal conductivity: Conventional circuits are air cooled for power densities up to $1 \mathrm{~W} / \mathrm{cm}^{2}$. For high speed circuits, liquid cooling techniques extend cooling capacity to $20 \mathrm{~W} / \mathrm{cm}^{2}$. Ceramic substrates can serve as a heat sink and are therefore preferred over polymer-based substrates for high performance circuits (Wilcox 1971).

1.1c Thermal expansion: During device assembly and use, thermal cycling can cause cracks to form in the solder joints often used to connect the chip to the ceramic substrate. To prevent chip detachment and device failure, it is important to match the thermal expansion coefficient of the substrate to that of Si (Wilcox 1971).

The list of desired properties for an ideal substrate material is formidable (table 1). The best candidates are covalent compounds of the light elements, and these are generally difficult to process. No one compound possesses all the desired properties for a substrate. Thus, different substrate materials are used depending on the specific application for the microelectronic package. If the overriding consideration is high speed, the emphasis will be on substrates with a dielectric constant of 3 or less. No dense inorganic material can achieve such a low $\kappa$, but inorganic materials containing high porosity are under very active consideration. The porosity must be closed in order to achieve hermeticity.

Materials with very low dielectric constant have relatively poor thermal conductivity; thus, heat must be dissipated in a manner not dependent on the substrate as a heat sink: In a high power application, the substrate must act as a very good heat sink. The material of choice in this case has been $\mathrm{BeO}$ which will probably be replaced by AlN due mainly to the toxicity of $\mathrm{Be}$ (table 2).

\subsection{Aluminosilicate-based ceramics as substrates}

Aluminosilicates offer certain advantages for use as packaging materials. Many aluminosilicate-based ceramics such as cordierite $\left(2 \mathrm{MgO} \cdot \mathrm{Al}_{2} \mathrm{O}_{3} \cdot 5 \mathrm{SiO}_{2}\right)(\mathrm{Genesse}$ and Chowdhry 1986), anorthite $\left(\mathrm{CaO} \cdot \mathrm{Al}_{2} \mathrm{O}_{3} \cdot 2 \mathrm{SiO}\right.$ ) (Gdula 1970; Hayashi and Fukui $1980)$ and mullite $\left(3 \mathrm{Al}_{2} \mathrm{O}_{3} \cdot 2 \mathrm{SiO}_{2}\right)$ (Mussler and Shafer 1984) have attracted attention in recent years as alternative substrate materials to conventionally used $\alpha$-alumina. They offer the advantages of lower dielectric constants and lower thermal expansion coefficients than those of alumina (table 2). They also offer the potential for lower sintering and densification temperatures than conventionally used for $\alpha$-alumina 
Table 2. Dielectric and thermal properties of selected substrate materials.

\begin{tabular}{|c|c|c|c|}
\hline & $\begin{array}{c}\text { Dielectric } \\
\text { constant } \\
\qquad\end{array}$ & $\begin{array}{c}\text { Thermal } \\
\text { expansion } \\
\alpha \times 10^{-6} /{ }^{\circ} \mathrm{C} \\
\left(25-400^{\circ} \mathrm{C}\right)\end{array}$ & $\begin{array}{l}\text { Thermal } \\
\text { conductivity } \\
\text { W/m K }\end{array}$ \\
\hline Diamond & 5.7 & 1.5 & 2000 \\
\hline SiC & 40 & 3.7 & 490 \\
\hline $\mathbf{S i}_{3} \mathbf{N}_{4}$ & 600 & 3.0 & 30 \\
\hline AIN & 8.8 & 4.5 & 320 \\
\hline BeO & 6.9 & 90 & 370 \\
\hline $\mathbf{A l}_{2} \mathbf{O}_{3}$ & 9.6 & 7.8 & 30 \\
\hline $\mathrm{SiO}_{2}$ (quartz) & 4.3 & $10-12$ & 7 \\
\hline $\mathrm{SiO}_{2}$ (glass) & 3.8 & 0.55 & 2 \\
\hline B/Si/O (glass) & $4 \cdot 1$ & $3 \cdot 3$ & 1.8 \\
\hline Hexagonal cordierite $\left(2 \mathrm{MgO}_{2} \cdot 2 \mathrm{Al}_{2} \mathrm{O}_{3} \cdot 5 \mathrm{SiO}_{2}\right)$ & $5-6$ & $1-2$ & $1-2$ \\
\hline Mullite $\left(3 \mathrm{Al}_{2} \mathrm{O}_{3} \cdot 2 \mathrm{SiO}_{2}\right)$ & 6.6 & 5.5 & $\overline{\mathbf{3}}$ \\
\hline Anorthite $\left(\mathrm{CaO} \cdot \mathrm{Al}_{2} \mathrm{O}_{3} \cdot 2 \mathrm{SiO}_{2}\right)$ & 70 & 4.8 & 2 \\
\hline$\beta$-Spodumene $\left(\mathrm{Li}_{2} \mathrm{O} \cdot \mathrm{Al}_{2} \mathrm{O}_{3} \cdot 4 \mathrm{SiO}_{2}\right)$ & 6.5 & $2 \cdot 1$ & 2 \\
\hline Polyimide & 2.2 & $20-50$ & 0.2 \\
\hline
\end{tabular}

$\left(1600^{\circ} \mathrm{C}\right)$. However, traditional processing involves the melting of the appropriate oxides at generally $>1400^{\circ} \mathrm{C}$, quenching to form a glass, and subsequent crystallization by a controlled heat treatment.

The cordierite family of glass-ceramics has a dielectric constant (5-6 at $1 \mathrm{MHz}$ ) lower than that of $\mathrm{Al}_{2} \mathrm{O}_{3}$ and potential for attractively low sintering temperatures. The average thermal expansion coefficient of cordierite is, however, very low (table 2). It has been shown (Mussler and Shafer 1984) that addition of mullite to cordierite allows tailoring of the thermal expansion coefficient of the composite. Thus, a composite consisting of $65 \mathrm{vol} \%$ cordierite and $35 \mathrm{vol} \%$ mullite has a thermal expansion coefficient matching that of $\mathrm{Si}$.

1.2a Ceramic processing: Having identified a material or combination of materials that satisfies the requirements described above, the next challenge is to process it into a dense, hermetic body of the desired shape below $1000^{\circ} \mathrm{C}$. In general, materials with strong covalent bonding that are desirable for their high thermal conductivity, low dielectric constant and low expansivity have low diffusivities and do not sinter readily (Chowdhry and Sleight 1987). From a practical standpoint, either reactive liquid phase sintering or viscous flow rather than solid state diffusion are the mechanisms adopted for processing of electronic ceramics. The processing of ceramics below $1000^{\circ} \mathrm{C}$ generally involves a liquid phase or viscous sintering mechanism. Control over the size distribution and packing of the particles prior to sintering as well as control over the system viscosity is essential to achieve a dense substrate at relatively low temperatures. During sintering, grain growth must be minimized because fine grained ceramics are needed for the smooth surfaces required for high resolution circuit patterns. Processing flaws must be minimized to achieve good mechanical properties. In addition, the systems selected should be stable, non-toxic and relatively inexpensive. 


\section{Zeolites as precursors to ceramic substrate materials}

Ceramics have traditionally been made by shaping natural or man-made powders into objects and subsequently densifying them. One of the major thrusts in recent ceramics research has been directed toward the development of materials with greatly improved mechanical reliability by improving the properties of the ceramic precursor. The conventional way of making fine powders is to grind a bulk material and pass it through a fine sieve. Although fine powders may result, they may not be uniform in size and grinding the material may introduce impurities. One method for preparing pure, superfine, uniform-sized powders is the sol-gel process (Zelinski and Uhlmann 1984; Roy 1987). The sol-gel method involves the conversion of a sol to a gel and subsequent drying. Although the sol-gel method offers a number of advantages over other techniques, such as better homogeneity because of mixing on the atomic scale, higher purity, uniform small particle size, and lower temperature of preparation, it does have a number of disadvantages. These include high cost of raw materials, large shrinkage during processing, residual fine pores, residual hydroxyls, residual carbon, health hazards of organic solutions, and long processing times.

Zeolites are crystalline aluminosilicate materials with open framework structures. Zeolites may be generally represented by the formula $\mathrm{M}_{2 / n} \cdot \mathrm{Al}_{2} \mathrm{O}_{3} \cdot x \mathrm{SiO}_{2} \cdot y \mathrm{H}_{2} \mathrm{O}$, where $M$ is a cation of valence $n, x$ is generally greater than or equal to 2 , and $y$ can vary from 0 to 10 . There are approximately 40 naturally occurring zeolites and over 100 synthetic forms (Breck 1984; Thomas and Catlow 1987; Dyer 1988). The synthetic forms are crystallized from aluminosilicate gels containing alkali metals. These alkali cations can generally be easily replaced by conventional ion-exchange of the crystalline zeolite. This ion-exchange ability allows homogeneous compositional variations on the atomic scale. As a result of properties such as high surface area, ion exchange capacity and molecular sieving ability, zeolites have found application in cracking, separations, drying and in detergent formulations. Several varieties (e.g. zeolites A, $\mathrm{X}$ and $\mathrm{Y}$ ) are commercially available in large volumes at relatively low cost. Table 3 lists the composition of zeolites $\mathrm{A}, \mathrm{X}$ and $\mathrm{Y}$, which are available commercially. The sodium in these zeolites can be replaced by other monovalent cations such as $\mathrm{Li}$ or $\mathrm{K}$; by divalent cations such as $\mathrm{Mg}, \mathrm{Ca}, \mathrm{Sr}, \mathrm{Ba}$ or $\mathrm{Pb}$; or by mixtures of cations, to the extent that charge neutrality is maintained. Many of the synthetic zeolites have compositions close to those of the desired aluminosilicate-based ceramics listed in table 4. The ion-exchange ability of zeolites allows homogeneous compositional variation on an atomic scale. This advantage, coupled with their uniform particle size and low cost, make zeolites very attractive precursors to aluminosilicate-based ceramics.

Table 3. Compositions of commercial zeolites.

\begin{tabular}{ll}
\hline Zeolite* & Composition \\
\hline Linde 4A & $\mathrm{Na}_{12} \mathrm{Al}_{12} \mathrm{Si}_{12} \mathrm{O}_{48} \cdot x \mathrm{H}_{2} \mathrm{O}$ \\
Linde 13X & $\mathrm{Na}_{86} \mathrm{Al}_{86} \mathrm{Si}_{106} \mathrm{O}_{384} \cdot x \mathrm{H}_{2} \mathrm{O}$ \\
Linde LZ-Y52 & $\mathrm{Na}_{56} \mathrm{Al}_{56} \mathrm{Si}_{136} \mathrm{O}_{384} \cdot x \mathrm{H}_{2} \mathrm{O}$ \\
\hline
\end{tabular}

*All zeolites obtained from Alfa Products Div, Danvers, MA, USA 
Table 4. Zeolite stoichiometry similar to desired ceramics.

\begin{tabular}{lll}
\hline Zeolite & Composition & Ceramic composition \\
\hline $\mathrm{Ca}-\mathrm{A}$ & $\mathrm{Ca}_{6} \mathrm{Al}_{12} \mathrm{Si}_{12} \mathrm{O}_{48}$ & $6 \mathrm{CaAl}_{2} \mathrm{Si}_{2} \mathrm{O}_{8}$ (anorthite) \\
$\mathrm{Ca}-\mathrm{X}$ & $\mathrm{Ca}_{43} \mathrm{Al}_{86} \mathrm{Si}_{106} \mathrm{O}_{384}$ & $43 \mathrm{CaAl}_{2} \mathrm{Si}_{2} \mathrm{O}_{8}+20 \mathrm{SiO}_{2}$ \\
$\mathrm{Mg}-\mathrm{Y}$ & $\mathrm{Mg}_{28} \mathrm{Al}_{56} \mathrm{Si}_{136} \mathrm{O}_{384}$ & $14 \mathrm{Mg}_{2} \mathrm{Al}_{4} \mathrm{Si}_{5} \mathrm{O}_{28}$ (cordierite) $+66 \mathrm{SiO}_{2}$ \\
$\mathrm{Li}-\mathrm{A}$ & $\mathrm{Li}_{12} \mathrm{Al}_{12} \mathrm{Si}_{12} \mathrm{O}_{48}$ & $12 \mathrm{Li}_{1-x} \mathrm{Al}_{1-x} \mathrm{Si}_{1+x} \mathrm{O}_{4}, x=0$ ( $\beta$-eucryptite) \\
$\mathrm{Li}-\mathrm{Y}$ & $\mathrm{Li}_{56} \mathrm{Al}_{56} \mathrm{Si}_{136} \mathrm{O}_{384}$ & $56 \mathrm{Li}_{x} \mathrm{Al}_{x} \mathrm{Si}_{1-x} \mathrm{O}_{2}, x=0-29$ ( $\beta$-spodumene) \\
$\mathrm{Ba}-\mathrm{A}$ & $\mathrm{Ba}_{6} \mathrm{Al}_{12} \mathrm{Si}_{12} \mathrm{O}_{48}$ & $6 \mathrm{BaAl}_{2} \mathrm{Si}_{2} \mathrm{O}_{8}$ (celsian) \\
\hline
\end{tabular}

In this section, we describe a novel route, namely the use of ion exchanged zeolites as precursors, to aluminosilicate-based ceramic substrates for microelectronics packaging applications.

\subsection{Preparation and characterization of zeolite precursors and ceramics}

Zeolites 4A(Na-A), 13X (Na-X), and LZ-Y52 (Na-Y) were exchanged by conventional ion exchange techniques with the various cations described in the text, generally using nitrate salts. The dry, exchanged zeolite powder was ground in an agate mortar for $15 \mathrm{~min}$ and then pressed into $13 \mathrm{~mm}$ pellets at $97 \mathrm{MPa}$. The pellets were then heated at $1^{\circ} \mathrm{C} / \mathrm{min}$ to the desired temperature and held there for $3 \mathrm{~h}$. Shrinkage was measured with an Ortön dilatometer. The density was determined using conventional techniques and with a helium autopycnometer. Hermeticity was determined by a dye penetration and a water absorption test. Dielectric properties were measured on sintered disks with sputtered gold electrodes. The capacitance and loss angle were measured at $1 \mathrm{MHz}$ using an HP 4275A LCR bridge and the dielectric constant, $\kappa$, was calculated using the formula $\kappa=c t / \varepsilon_{0} A$, where $t$ is the sample thickness, $A$ the electrode area, and $\varepsilon_{0}$ the permittivity constant. The resistivity was measured using a Keithley 617 electrometer. The coefficient of linear thermal expansion was measured using an Orton dilatometer in the range $25^{\circ}$ to $400^{\circ} \mathrm{C}$. X-ray powder diffraction data were obtained using a Phillips APD 3600, a Phillips APD 3700, or a Scintag PAD-5 diffractometer.

\subsection{Anorthite-based ceramics from $\mathrm{Ca}-\mathrm{X}$ zeolites}

A series of $\mathrm{Ca}$-exchanged $\mathrm{Na}-\mathrm{A}, \mathrm{Na}-\mathrm{X}$ and $\mathrm{Na}-\mathrm{Y}$ zeolites with varying $\mathrm{Si} / \mathrm{Al}$ contents was prepared using the ion-exchange technique (Subramanian et al 1989). These zeolites were converted to anorthite $\left(\mathrm{CaAl}_{2} \mathrm{Si}_{2} \mathrm{O}_{8}\right)$ as follows:

$$
\begin{aligned}
& \mathrm{Ca}-\mathrm{A}:\left(\mathrm{Ca}_{6} \mathrm{Al}_{12} \mathrm{Si}_{12} \mathrm{O}_{48}\right) \rightarrow 6 \mathrm{CaAl}_{2} \mathrm{Si}_{2} \mathrm{O}_{8} \text { (anorthite) } \\
& \mathrm{Ca}-\mathrm{X}:\left(\mathrm{Ca}_{43} \mathrm{Al}_{86} \mathrm{Si}_{106} \mathrm{O}_{384}\right) \rightarrow 43 \mathrm{CaAl}_{2} \mathrm{Si}_{2} \mathrm{O}_{8}+20 \mathrm{SiO}_{2} \\
& \mathrm{Ca}-\mathrm{Y}:\left(\mathrm{Ca}_{28} \mathrm{Al}_{56} \mathrm{Si}_{136} \mathrm{O}_{384}\right) \rightarrow 28 \mathrm{CaAl}_{2} \mathrm{Si}_{2} \mathrm{O}_{8}+80 \mathrm{SiO}_{2}
\end{aligned}
$$

Virtually no shrinkage occurs up to $700^{\circ} \mathrm{C}$. This is a desired processing advantage from the point of view of binder removal (Subramanian et al 1989). The pores in the 
material remain open to high enough temperatures that complete binder removal is effected. At $750^{\circ} \mathrm{C}$, a sharp change in sample dimensions, characteristic of liquid phase sintering, is revealed. Zeolites are metastable materials, whose structure collapses above a certain temperature. The $\mathrm{X}$-ray diffraction patterns (figure 2 ) indicate that at $800^{\circ} \mathrm{C}$, the material is still crystalline $\mathrm{Ca}-\mathrm{X}$ zeolite. By $850^{\circ} \mathrm{C}$, the structure has collapsed, and the material is now completely amorphous. Above $900^{\circ} \mathrm{C}$, anorthite has recrystallized from the glassy matrix. At $950^{\circ} \mathrm{C}$, the sample is dense and hermetic.

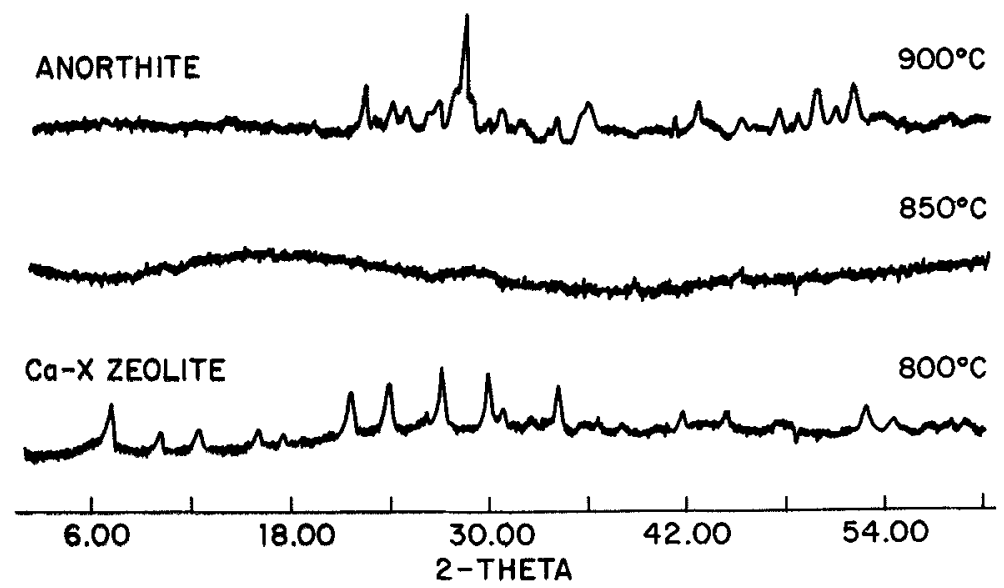

Figure 2. $X$-ray diffaction data showing the formation of an anorthite phase at $900^{\circ} \mathrm{C}$ from $\mathrm{Ca}-\mathrm{X}$ zeolite.

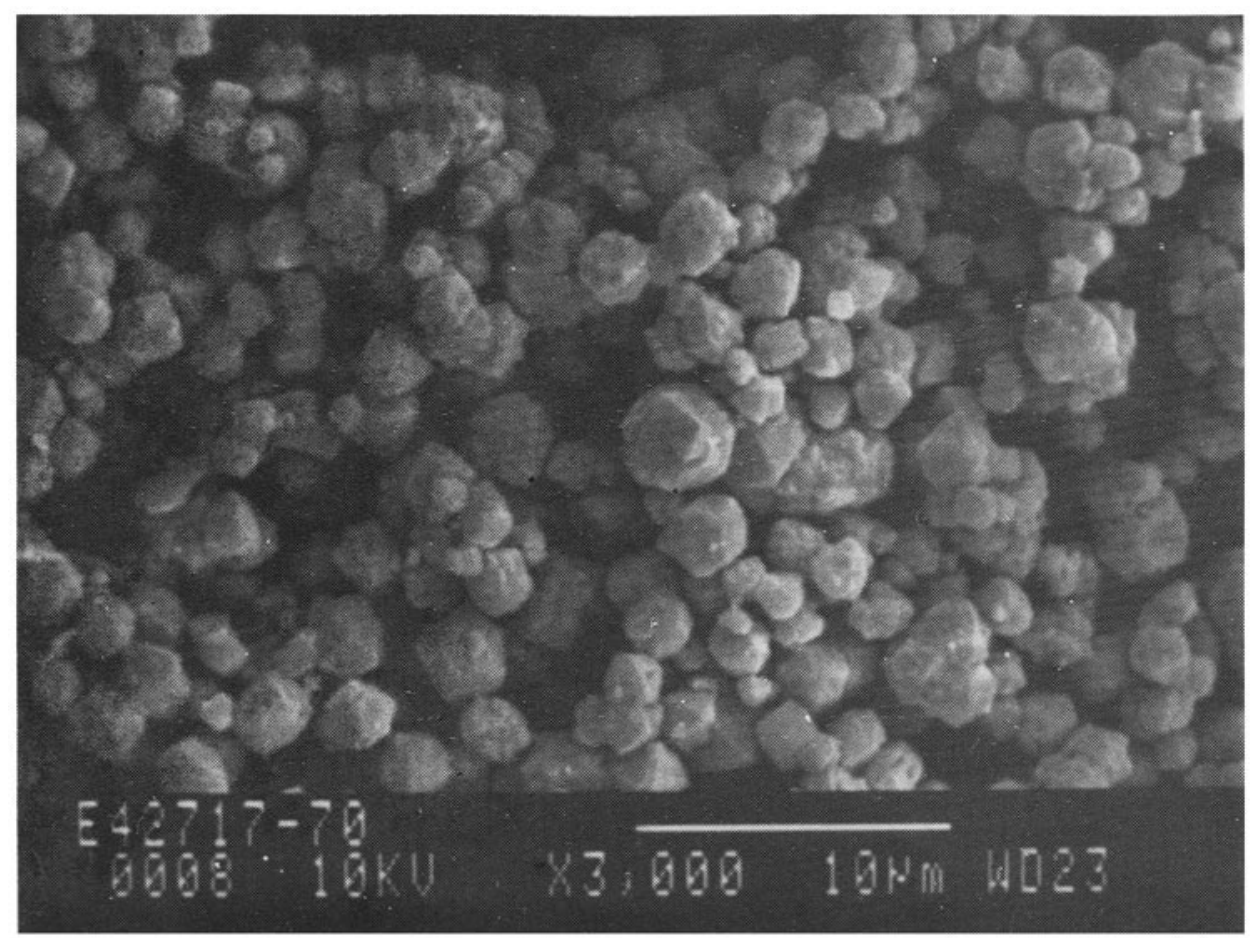

Figure 3. Scanning electron micrograph of $\mathrm{Ca}-\mathrm{X}$ zeolite powder. 

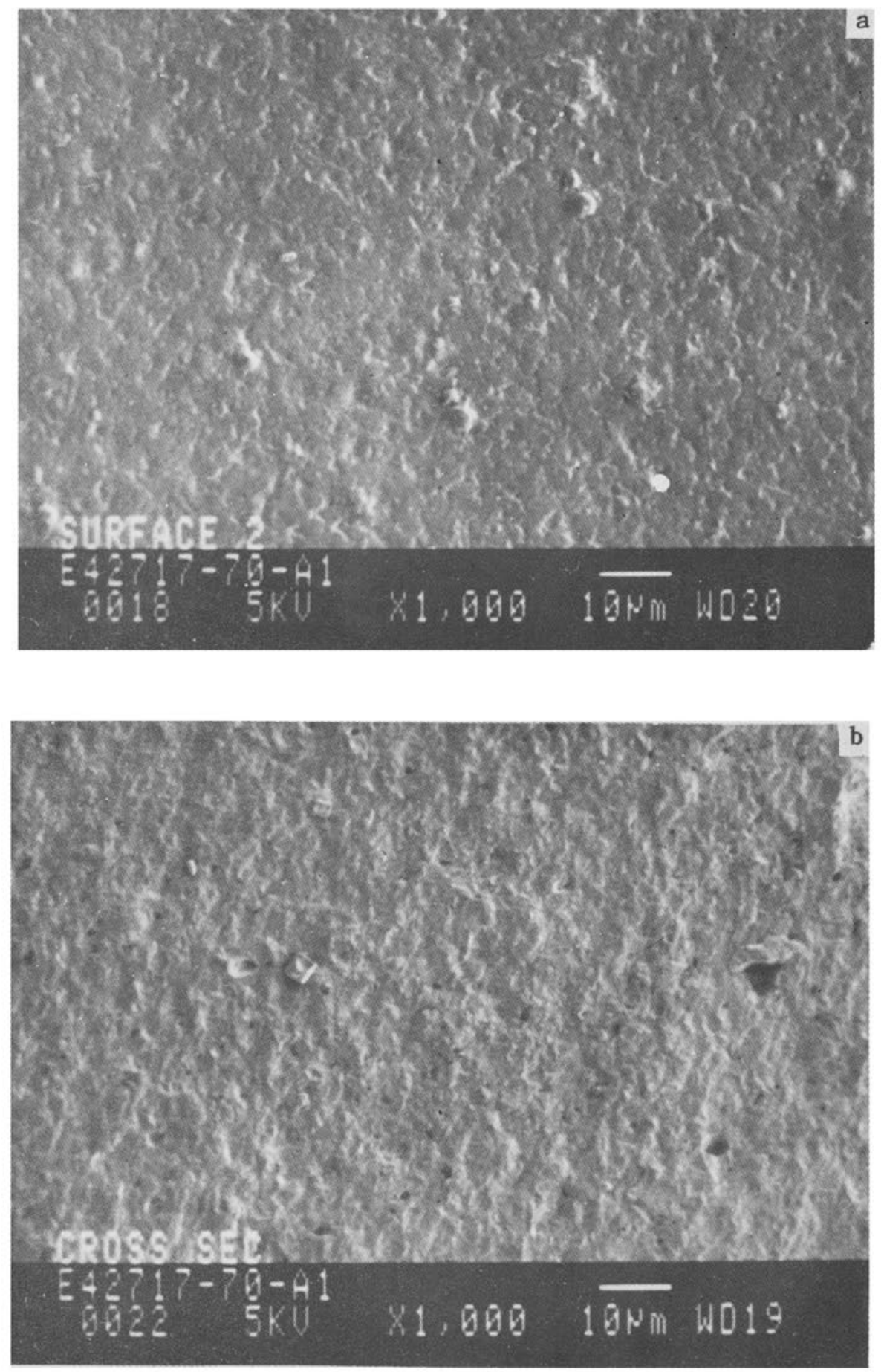

Figure 4. Scanning electron micrograph of anorthite-based ceramics from $\mathrm{Ca}-\mathrm{X}$ zeolite: (a) surface and (b) cross section. 
The process sequence from crystalline to amorphous to crystalline material is desirable for low temperature sintering and densification. Figure 3 indicates the nature of the powder packing for $\mathrm{Ca}-\mathrm{X}$ zeolite prior to firing. The particle size distribution and the pore size distribution are relatively narrow. When heated, the material is densified by viscous flow. It is desirable to achreve complete densification of the material in the glassy state prior to crystallization. The fired microstructures (figures $4 \mathrm{a}$ and b) show a dense surface and a fracture surface, with a few isolated pores. If the heating schedule is optimized, complete densification can be achieved in the glassy state. Recrystallization of the glass to form anorthite is accompanied by $\approx 40 \%$ volume change, but this change is not significant enough to cause cracking (Subramanian et al 1989). The final average grain size of the anorthite formed after crystallization is $<1 \mu \mathrm{m}$.

The properties of the sintered material prepared from $\mathrm{Ca}-\mathrm{X}$ are shown in table 5 . The densification temperature of $900^{\circ} \mathrm{C}$ is attractively low. The dielectric constant at $1 \mathrm{MHz}$ is 6.5 , with a low loss of $6 \times 10^{-4}$. The dielectric constant can be lowered if excess silica is used, but this lower value does cause mechanical properties to degrade. The linear thermal expansion coefficient of the anorthite made from $\mathrm{Ca}-\mathrm{X}$ is $4.2 \times 10^{-6} /{ }^{\circ} \mathrm{C}$, a very close match to that of $\mathrm{Si}$ (table 1 ).

In the preparation of anorthite from zeolite precursors, the alkali metal containing zeolite can be first exchanged with ammonium nitrate to give the ammonium form of the zeolite. This step is incorporated into the preparation to help guarantee the removal of undesired alkali ions that can seriously affect the dielectric properties of the resulting ceramic (Corbin et al 1991). The effect of residual sodium in the zeolite on the dielectric loss of anorthite ceramics derived from $\mathrm{Ca}-\mathrm{X}$ zeolite is illustrated in figure 5 . In this example, only after about $95 \%$ of the sodium has been removed does the dielectric loss fall below the maximum desired level (0.001).

\subsection{Anorthite-cordierite-based composite ceramics from $\mathrm{Ca}, \mathrm{Mg}-\mathrm{X}$ zeolites}

Although anorthite is a very attractive material for electronic packaging itself, superior properties are found in a composite of anorthite and hexagonal cordierite. Adding hexagonal cordierite to anorthite lowers the dielectric constant further, causing a better match of the thermal expansion coefficient to that of $\mathrm{Si}$.

Table 5. Anorthite-based ceramic substrate properties (from $\mathrm{Ca}-\mathrm{X}$ zeolite).

\begin{tabular}{lc}
\hline Composition (wt\%) & \\
$\mathrm{CaO}$ & 14.94 \\
$\mathrm{Al}_{2} \mathrm{O}_{3}$ & 33.22 \\
$\mathrm{SiO}_{2}$ & 51.21 \\
$\mathrm{Na}_{2} \mathrm{O}$ & 0.63 \\
Sintering temperature & $900^{\circ} \mathrm{C}$ \\
Density & $>98 \%$ \\
Water absorption & $0 \%$ \\
Dielectric constant $(x)$ & 6.5 \\
Dielectric loss & 0.0006 \\
Insulation resistant $(\Omega \cdot \mathrm{cm})$ & $>10^{13}$ \\
Thermal expansion $/{ }^{\circ} \mathrm{C}$ & $4.2 \times 10^{-6}$ \\
\hline
\end{tabular}




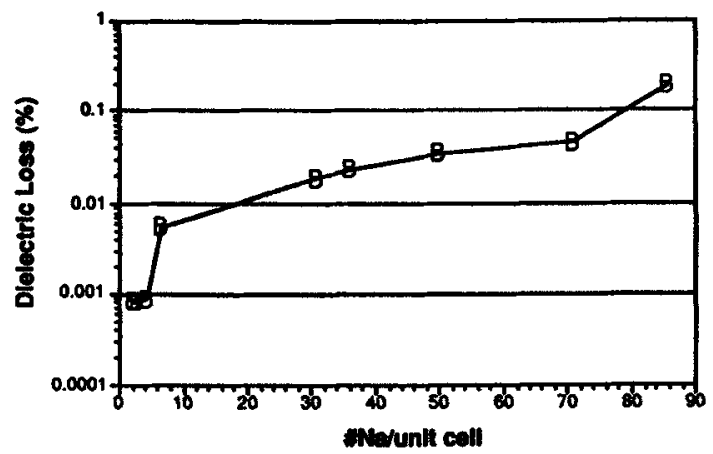

Figure 5. Effect of residual sodium content on the dielectric loss for anorthite ceramics derived from $\mathrm{Ca}-\mathrm{X}$ zeolite sintered at $1050^{\circ} \mathrm{C}$.

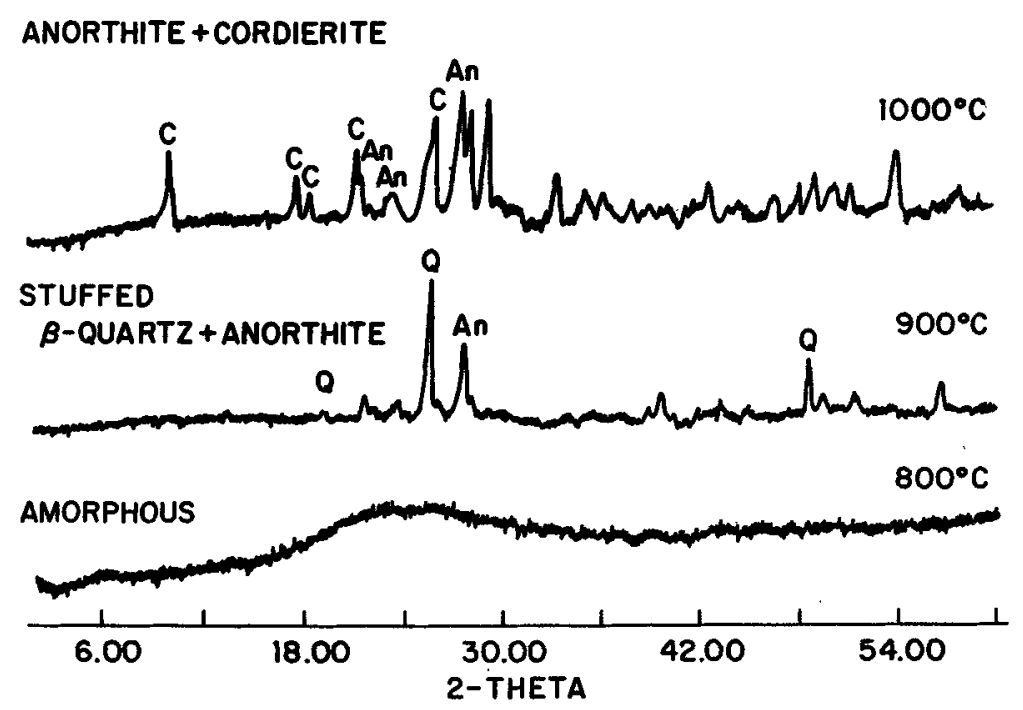

Figure 6. $\mathrm{X}$-ray diffraction data showing the formation of anorthite-cordierite-based composite ceramic from $\mathrm{Ca}, \mathrm{Mg}-\mathrm{X}$ zeolite.

A suitable zeolite precursor for anorthite-cordierite-based ceramics was prepared by partial exchange of $\mathbf{M g}$ for $\mathrm{Ca}$ in $\mathrm{Ca}-\mathrm{X}$, as described earlier. Chemical analysis of the precursor powder showed that $\approx 50 \%$ of $\mathrm{Ca}$ in $\mathrm{Ca}-\mathrm{X}$ was replaced by $\mathrm{Mg}$. The precursor powder had a narrow particle size distribution of 1 to $4 \mu \mathrm{m}$. The above-mentioned powder in pellet form was heated to various temperatures in the range $700^{\circ}$ to $1400^{\circ} \mathrm{C}$. The $\mathrm{XRD}$ patterns (figure 6) show that at $800^{\circ} \mathrm{C}$ the structure collapses and the material is completely amorphous. At $900^{\circ} \mathrm{C}$, in addition to anorthite, formation of a stuffed $\beta$-quartz type phase is noted. With further heating to $1000^{\circ} \mathrm{C}$, the stuffed $\beta$-quartz converts to cordierite, and with this conversion the dielectric constant decreases significantly. In table 6 , a summary of the phases formed and dielectric properties of $\mathrm{Mg}, \mathrm{Ca}-\mathrm{X}$ zeolite sintered at various temperatures is given.

The properties of $\alpha-\mathrm{Al}_{2} \mathrm{O}_{3}$, anorthite prepared from $\mathrm{Ca}-\mathrm{X}$; anorthite-cordierite composites prepared from $\mathrm{Ca}, \mathrm{Mg}-\mathrm{X}$; and cordierite prepared from $\mathrm{Mg}-\mathrm{Y}$ are compared in table 7. This comparison clearly shows that aluminosilicate-based ceramics 
Table 6. Summary of phases formed and dielectric properties of $\mathrm{Mg}, \mathrm{Ca}-\mathrm{X}(\sim 50 \% \mathrm{Mg}$ exchanged)* zeolite sintered at various temperatures.

\begin{tabular}{|c|c|c|c|}
\hline $\begin{array}{l}\text { Sintering } \\
\text { temp. }\left({ }^{\circ} \mathrm{C}\right)\end{array}$ & Phases formed ${ }^{\dagger}$ & $\begin{array}{c}\text { Dielectric constant } \\
\kappa \text {, at } 1 \mathrm{MHz}\end{array}$ & $\begin{array}{c}\text { Dielectric loss } \\
\tan \delta \text { at } 1 \mathrm{MHz}\end{array}$ \\
\hline 900 & Anorthite $(30)+\beta$-Quartz (70) & 7.9 & 0.0005 \\
\hline 1000 & Cordierite (45) + Anorthite (30) $+\beta$-Quartz (25) & $5 \cdot 8$ & 0.0009 \\
\hline 1050 & Cordierite $(55)+$ Anorthite $(30)+\beta$-Quartz (15) & 5.5 & 0.0010 \\
\hline 1200 & Cordierite (65) + Anorthite (30) + $\beta$-Quartz (5) & $5 \cdot 3$ & 0.0009 \\
\hline 1300 & Cordierite $(70)+$ Anorthite $(30)$ & $5 \cdot 2$ & 0.0005 \\
\hline 1400 & Mullite + Glass & - & - \\
\hline
\end{tabular}

* Chemical composition: $\mathrm{Ca}_{17} \mathrm{Mg}_{22}\left(\mathrm{NH}_{4}\right)_{3} \mathrm{NaAl}_{86} \mathrm{Si}_{106} \mathrm{O}_{384} \cdot x \mathrm{H}_{2} \mathrm{O}$.

${ }^{+} \mathrm{Mol} \%$ of phases formed are given in parentheses.

Table 7. Electrical and thermal properties of anorthite- and cordierite-based ceramics derived from zeolites. Values for alumina ceramic are given for comparison.

\begin{tabular}{lccccc}
\hline Ceramic & $\begin{array}{c}\text { Dielectric } \\
\text { constant } \kappa \\
\text { at } 1 \mathrm{MHz}\end{array}$ & $\begin{array}{c}\text { Dielectric } \\
\text { loss tan } \delta \\
\text { at } 1 \mathrm{MHz}\end{array}$ & $\begin{array}{c}\text { Resistivity } \\
(\mathrm{ohm}-\mathrm{cm})\end{array}$ & $\begin{array}{c}\text { Thermal } \\
\text { expansion } \\
\left(\times 10^{-6} /{ }^{\circ} \mathrm{C}\right)\end{array}$ & $\begin{array}{c}\text { Sintering } \\
\text { temp. } \\
\left({ }^{\circ} \mathrm{C}\right)\end{array}$ \\
\hline $\mathrm{An}-\mathrm{X}^{*}$ & 6.6 & 0.0006 & $>10^{13}$ & 4.4 & 900 \\
$\mathrm{An}-\mathrm{Cor}-\mathrm{X}^{\dagger}$ & $5 \cdot 6$ & 0.0009 & $>10^{13}$ & 3.3 & 1000 \\
$\mathrm{Cor}-\mathrm{Y}^{++}$ & $5 \cdot 2$ & 0.0020 & $>10^{12}$ & $2 \cdot 1$ & 1050 \\
$\mathrm{Al}_{2} \mathrm{O}_{3}$ & 9.6 & 0.0002 & $>10^{14}$ & 7.8 & 1500 \\
\hline
\end{tabular}

*An-X, anorthite obtained from $\mathrm{Ca}-\mathrm{X}$ zeolite.

${ }^{\dagger} \mathrm{An}-\mathrm{Cor}-\mathrm{X}$, anorthite-cordierite from $\mathrm{Ca}, \mathrm{Mg}-\mathrm{X}$ zeolite.

${ }^{+\dagger} \mathrm{Cor}-\mathrm{X}$, cordierite from $\mathrm{Mg}, \mathrm{NH}_{4}-\mathrm{Y}$ zeolite.

prepared from zeolites have desirably lower sintering temperatures, lower dielectric constants and lower thermal expansion coefficients compared to conventionally used $\alpha$-alumina. The $\alpha$-alumina substrates would, however, have a higher thermal conductivity, as well as higher mechanical strength and toughness.

\subsection{Cordierite-based ceramics from $\mathrm{Mg}, \mathrm{NH}_{4}-\mathrm{Y}$ zeolites}

Sintering of $\mathrm{Mg}, \mathrm{NH}_{4}-\mathrm{Y}\left(\mathrm{Mg}: \mathrm{NH}_{4}=2 \cdot 2,1 \cdot 73 \%\right.$ residual $\left.\mathrm{Na}_{2} \mathrm{O}\right)$ at $1100^{\circ} \mathrm{C}$ resulted in a dense, cordierite-based ceramic with a dielectric constant of $5 \cdot 2$, a dielectric loss of 0.002 , volume resistivity of $10^{12} \mathrm{ohm}-\mathrm{cm}$ and a coefficient of thermal expansion of $2.1 \times 10^{-6} \% \mathrm{C}$ (table 7 ).

\section{$2.5 \beta$-Spodumene and $\beta$-eucryptite ceramics from Li-exchanged zeolites}

Firing of $\mathrm{Li}-\mathrm{A}\left(2 \cdot 62 \%\right.$ residual $\left.\mathrm{Na}_{2} \mathrm{O}\right)$ and $\mathrm{Li}-\mathrm{X}\left(2.64 \%\right.$ residual $\left.\mathrm{Na}_{2} \mathrm{O}\right)$ zeolites at $1050^{\circ} \mathrm{C}$ gives $\beta$-eucryptite as the major component. $\mathrm{Li}-\mathrm{X}$ when heated to $1200^{\circ} \mathrm{C}$ converts to a $\beta$-spodumene related solid solution. At $700^{\circ} \mathrm{C}$, zeolite $\mathrm{Li}-\mathrm{Y}(3.36 \%$ residual $\mathrm{Na}_{2} \mathrm{O}$ ) is transformed into an amorphous phase and upon further heating to $800^{\circ} \mathrm{C}$ formation of lithium aluminosilicate with high-quartz structure is observed. When 


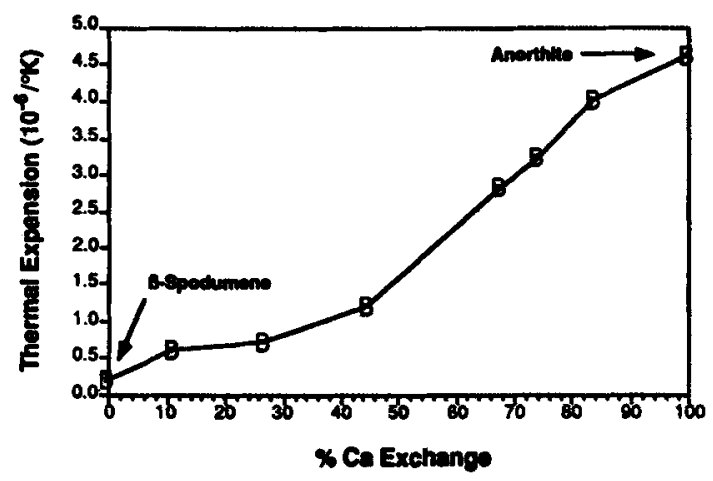

Figure 7. Effect of degree of calcium exchange on coeficient of thermal expansion for $\beta$-spodumene/anorthite composites derived from $\mathrm{Li}, \mathrm{Ca}-\mathrm{Y}$ zeolites sintered at $1000^{\circ} \mathrm{C}$.

Table 8. Other ceramics from zeolites.

\begin{tabular}{ll}
\hline Zeolite & Ceramic $\left(1050^{\circ} \mathrm{C}\right)$ \\
\hline $\mathrm{Ba}-\mathrm{A}, \mathrm{Ba}-\mathrm{X}, \mathrm{Ba}-\mathrm{Y}$ & $\mathrm{BaAl}_{2} \mathrm{Si}_{2} \mathrm{O}_{8}$ (celsian) \\
$\mathrm{Pb}-\mathrm{A}, \mathrm{Pb}-\mathrm{X}, \mathrm{Pb}-\mathrm{Y}$ & $\mathrm{PbAl}_{2} \mathrm{Si}_{2} \mathrm{O}_{8}$ \\
$\mathrm{NH}, 4, \mathrm{NH}, \mathrm{X}, \mathrm{NH}_{4}-\mathrm{Y}$ & $\mathrm{Al}_{6} \mathrm{Si}_{2} \mathrm{O}_{13}$ (mullite) \\
$\mathrm{Zn}-\mathrm{A}, \mathrm{Zn}-\mathrm{X}, \mathrm{Zn}-\mathrm{Y}$ & $\mathrm{ZnAl}_{2} \mathrm{O}_{4}$ \\
$\mathrm{Mg}, \mathrm{NH} \mathrm{H}_{4}-\mathrm{A} ; \mathrm{Mg}, \mathrm{NH}_{4}-\mathrm{X}$ & $\mathrm{MgAl}_{2} \mathrm{O}_{4}$ (spigel), $\mathrm{Al}_{6} \mathrm{Si}_{2} \mathrm{O}_{13}$ (mullite) \\
$\mathrm{Na}-\mathrm{A}, \mathrm{Na}-\mathrm{X}, \mathrm{Na}-\mathrm{Y}$ & $\mathrm{NaAlSi}_{3} \mathrm{O}_{8}$ (albite) \\
$\mathrm{K}-\mathrm{A}, \mathrm{K}-\mathrm{X}, \mathrm{K}-\mathrm{Y}$ & $\mathrm{KAlSi}_{2} \mathrm{O}_{6}$ \\
\hline
\end{tabular}

heated above $900^{\circ} \mathrm{C}$, the high-quartz structure is transformed into a $\beta$-spodumene related solid solution. X-ray and MASNMR studies (Subramanian et al 1986) indicate that the $\beta$-spodumene solid solution has a composition close to $\left(\mathrm{Li}_{0.23} \mathrm{Na}_{0.06}\right) \mathrm{Al}_{0.29}$ $\mathrm{Si}_{0.71} \mathrm{O}_{2}$, which is in agreement with chemical analysis.

\subsection{B-Spodumene/anorthite ceramics from $\mathrm{Li}, \mathrm{Ca}-\mathrm{Y}$ zeolites}

Sintering of $\mathrm{Li}, \mathrm{Ca}-\mathrm{Y}$ zeolites with varying amounts of calcium results in $\beta$-spodumene/ anorthite composites as determined by $\mathrm{X}$-ray powder diffraction. The addition of calcium results in improved dielectric loss $(0.001$ for $\mathrm{Li}, \mathrm{Ca}-\mathrm{Y}$ vs 0.01 for $\mathrm{Li}-\mathrm{Y})$ and the ability to vary the thermal expansion coefficient by varying the calcium content. This is shown in figure 7.

\subsection{Other ceramics from zeolites}

Some of the other ceramics prepared from zeolites as precursors are listed in table 8. Generally, aluminosilicate materials are obtained; however, it is interesting that for the smaller ions magnesium and zinc, the aluminate is formed instead of the aluminosilicate. In the case of the Mg-exchanged zeolites at 900 to $1050^{\circ} \mathrm{C}$, a mixed phase material is obtained containing spinel and mullite. It is reported that $\mathbf{M g}-\mathrm{X}$ gives cordierite under more severe conditions, i.e. after glass formation at $1500^{\circ} \mathrm{C}$ and heating at $1000^{\circ} \mathrm{C}$ (Breck 1984). 


\section{EXAFS characterization of the transformation of zeolites to aluminosilicate ceramics}

The decomposition of zeolite precursors is a novel route for the preparation of aluminosilicate-based substrate materials (Subramanian et al 1986, 1989; Chowdhry et al 1989; Parise et al 1989; Bedard and Flanigen 1990; Corbin et al 1991). While the structural reconstruction of zeolites to more dense phases is known, little is understood of the mechanism of this process. Studies of structural rearrangement in a variety of solid state materials is often hampered by the intermediate's lack of long range order (crystallinity). In these cases the traditional techniques of X-ray and neutron powder crystallography give way to the spectroscopies. EXAFS (extended $\mathrm{X}$-ray absorption fine structure) offers the opportunity to compare crystalline starting materials, where geometries are well characterized, with amorphous intermediates to decide whether the whole process is reconstructive or whether certain elements of structure are retained during the transition. We have examined the reconstructive transition from $\mathrm{Sr}-\mathrm{A}$ zeolite, through $\mathrm{X}$-ray amorphous intermediates, to $\mathrm{Sr}$-anorthite by EXAFS and have shown that the environment around the strontium remains essentially intact (Parise et al 1989). The strontium is coordinated near a flat 6-ring in $\mathrm{Sr}-\mathrm{A}$, sandwiched between a double 6-ring in $\mathrm{Sr}$-hexacelsian, and between layers in $\mathrm{Sr}$-anorthite. Although the intermediate amorphous materials produced at $850^{\circ} \mathrm{C}$ and $900^{\circ} \mathrm{C}$ have quite similar $\mathrm{X}$-ray powder patterns, they have very different EXAFS spectra. The Fourier transform for the $850^{\circ} \mathrm{C}$ sample is very similar to that of dehydrated $\mathrm{Sr}-\mathrm{A}$, the $900^{\circ} \mathrm{C}$ sample is more similar to $\mathrm{Sr}$-hexacelsian. These similarities can be explained if the primary coordination about the $\mathrm{Sr}$ in $\mathrm{Sr}-\mathrm{A}$ is maintained.

\section{Summary}

Zeolites offer promise as precursors to aluminosilicate-based ceramics: they are readily synthesized, with a narrow particle size distribution, and can be obtained at low cost. Their ion exchange properties allow a wide range of possibilities for the precursor composition. When heated, zeolites become amorphous and densify at relatively low temperatures, by viscous flow prior to crystallization to the desired ceramic. The dielectric and thermal expansion properties, in addition to the processing advantages, make anorthite and anorthite-cordierite composite ceramics prepared from zeolite precursors very attractive substrate candidates for use in microelectronic packaging.

\section{References}

Bedard R L and Flanigen E M 1990 US Patent 4890323

Breck D W 1984 Zeolite molecular sieves (Malabar, FL: Robert E Krieger Publishing) pp $493-498$ and references therein

Chowdhry U and Sleight A W 1987 Ann. Rev. Mater. Sci. 17323

Chowdhry U, Corbin D R and Subramanian M A 1989 US Patent 4814303

Corbin D R, Parise J B, Chowdhry U and Subramanian M A 1991 Mater. Res. Soc. Sym. Proc. 223213

Dyer A 1988 Zeolite molecular sieves (Great Britain: John Wiley and Sons) p. 12

Genesse C and Chowdhry U 1986 in Better ceramics through chemistry II (eds) C J Brinker, D E Clark and D R Ulrich (Pittsburgh, PA: Mater. Res. Soc. Proc. 73) pp 693-703 
Gdula R 1970 Am. Ceram. Soc Bull. 50555

Harper C A and Staley W E 1985 Electr. Packag. Prod. 58

Hayashi K and Fukui M 1980 Sci. Technol. 2958

von Hippel A R 1954 Dielectrics and waves (New York: John Wiley and Sons) p. 95

Mussler B H and Shafer M W 1984 Am. Ceram. Soc. Bull. 635

Parise J B, Corbin D R and Subramanian M A 1989 Mater. Res. Bull. 24303

Roy R 1987 Science 2381664

Schwartz B 1984a J. Phys. Chem. Solids 451051

Schwartz B 1984b Am. Ceram. Soc. Bull. 63577

Subramanian M A, Corbin D R and Farlee R D 1986 Mater. Res. Bull. 211525

Subramanian M A, Corbin D R and Chowdhry $U 1989$ in Ceramic substrates and packages for electronic applications (eds) M F Yan, K Niwa, H M O'Bryan Jr. and W S Young (Westerville, OH: Adv. in Ceramics 26) pp 239-247

Thomas J M and Catlow C R A 1987 in Progress in inorganic chemistry (ed.) S J Lippard (New 'York: Wiley and Sons) Vol. 35 p. 1

Tummala R R 1988 Am. Ceram. Soc. Bull. 67752

Wilcox D L 1971 Solid State Technol. 40

Zelinski B J J and Uhlmann D R 1984 J. Phys. Chem. Solids 451069 